https://doi.org/10.31874/2520-6702-2021-12-2-88-99

UDC -378

Doctor of Science in Philosophy, Professor, Head of Department of Modern Problems of Philosophy, Institute of Philosophy, National Academy of Sciences of Azerbaijan

kila50@mail.ru

\title{
Perspectives of the future and global leadership: ideas and concepts
}

In the article a comparative analysis of the concepts of S. Huntington, F. Fukuyama and I. Wallerstein is carried out in order to identify the theoretical and methodological foundations of the coming future. I. Wallerstein's post-nonclassical ideas foreshadowing the crisis of liberalism and the need to transform the foundations of Western democracy, the collapse of capitalism development paradigms, the growing interconnection of populism and authoritarianism, the formation of a new transitional period characterized by systemic disorder (chaos), acute political struggle on the principle "all against all", lack of peaceful coexistence, stability and legality are most adequately reflected in the modern political process. In general, the future appears as a bundle of scenarios of varying degrees of probability, only some of which, bypassing the zones of uncertainty, can take place. This approach significantly changes the approach to higher education and the teaching of the humanities and social sciences.

The second part of the article discusses the issues of defining the future by preceding events, highlighting the main and peripheral events that lay the foundation for the future. It is noted that even before the pandemic, the flaws of democracy and the growth of anti-liberal and anti-globalist sentiments in the world became noticeable, leading to national insularity, strengthening xenophobia, contributing to the growth of authoritarian regimes and their image in populist terms. It is emphasized that the majority of contemporary forecasts are alarmist in nature, they are value colored by deep pessimism and apocalyptic sentiments.

Each country will have to cope with threats on its own, because the world must go through destructive processes in order to establish a new order, confirming Wallerstein's predictions. paradigms.

As you can see, we are talking about a serious reduction in the philosophy of education and its systemic

Key words: future, philosophy of time, higher education, post-non-classical cognition, forecasting, global leadership, political analysis.

\section{Introduction}

The future has always attracted the attention of mankind, striving to predict perspective as much as knowledge and creative imagination allowed. In the course of historical development there has been a steady tendency to narrow the gap between prediction and its approbation by reality. This tendency made it possible to identify erroneous and true preconditions of forecasts and their value bases, revealing the socio-cultural determination of cognition. As a result: the accepted paradigmatic nature of some of the forecasts contributed, on the one hand, to the ordering of knowledge about social processes, on the other hand, to the formation of stable stereotypes, crowding out from the research space many fruitful ideas and theories that contradict the conceptual provisions of the accepted paradigm.

A good example of the latter are the ideas of two articles published at the end of the last century under the "question mark»: «The End of History?» by Francis Fukuyama (1989, National 
Interest) and «The Clash of Civilizations? by Samuel Huntington (1993, Foreign Affairs). A few years later, on the wave of worldwide success of their concepts, both authors published monographs without the «question mark»: «The End of History and the Last Man» (1992) and "The Clash of Civilizations» (1996). (1996), on which several generations of the world's students were trained. The main ideas of these books are well known. Samuel Phillips Huntington (1927-2008) believed that after the collapse of the Soviet Union, the dynamics of world processes would be determined by inter-civilizational conflicts arising from the clash of conflicting cultural identities. Since Huntington saw the greatest difference in identities between Western and Islamic culture, his prediction of a «major clash» of the future, seemingly confirmed by the events of September 11, 2001, has become a paradigmatic stereotype (Huntington, 2015).

Yoshihiro Francis Fukuyama (1952) interpreted the same event (the collapse of the USSR) as the "end of history», culminating in the principles of liberal democracy, which in the packaging of neoliberal ideology and economy were to march victoriously through all states and societies of the world (Fukuyama, 2015).

The article correlates Huntington's and Fukuyama's constructs with the ideas of the prominent American sociologist Immanuel Maurice Wallerstein (1030-2019) and validates them with a comparative analysis of ongoing political processes and their theoretical description by contemporary political philosophy.

In this regard, the following questions are the subject of the article: what have the past 3035 years confirmed and refuted in the constructs of Huntington and Fukuyama and Wallerstein's ideas? To what extent has the future justified the predictions of these thinkers? Is it possible to formulate working methodological principles for the philosophy of the future on the basis of this discussion? In what way will they differ from the mechanistic principles of cause and effect, which methodologically served classical and non-classical cognition?

What effects will the post-non-classical paradigm have on educational philosophy and the teaching of social sciences and humanities in institutions of higher education?

\section{Comparativism of the Paradigms of Future}

The collapse of the USSR was a world-historical event from which most specialists in the philosophy of politics, and after them representatives of other social sciences and professions, began to keep an account of the new era of human development. Thus, Michel Duclos (former French diplomat, special adviser to the Institute de Montaigne) noted that with the collapse of socialism, all political legitimacy in the world shifted to liberalism, expressed in a desire to master the basics of economic liberalism as the foundation for the development of states and societies. Fukuyama recorded precisely this victory of neoliberalism, which only a quarter of a century later began to look pyrrhic. The period of a sharp increase in the aggressiveness of neoliberalism (the era of expansionism), which resulted in a number of wars of conquest, was not envisaged by Fukuyama. M. Duclos believes that at the turn of 2014-2016 there was a geopolitical shift that changed people's thinking. "Interesting processes began to occur that had not previously been inherent in world development... The world entered a period of «new authoritarian leaders»: «strong personalities», autocrats, populist leaders and other dictators began to define the spirit of the times» (Duclos 2018). Let us note in this regard that the events taking place were predicted by S. Huntington's theory of «waves and rollbacks of democratization» (Huntington, 2003). 
What do contemporary political leaders (Donald Trump, Xi Jinping, Vladimir Putin, Narendra Modi, or the «second string» politicians: Recep Tayyip Erdogan, Viktor Orban, Benjamin Netanyahu, Mohammed Ben Salman, Jair Bolsonaro, Matteo Salvini) have in common and separate? «These characters come from different walks of life, some are established dictators, others lead straying democracies, others are in transition. All of them, to varying degrees, certainly use a kind of antiliberal toolkit where nationalism, kleptocracy, centralization of power, restriction of freedoms, contempt for the rule of law, and claims to embody the aspirations of the people are piled up» (Duclos, 2018).

The contemporary political arena is characterized more by the union of populism and authoritarianism than by the unity of democracy and liberalism. Figures as opposed to each other as D. Trump and V. Putin, each in his own way struggling with the ideas of European integration and forming a «parallel anti-liberal space» in the world of politics. M. Duclos' prediction of the outcome of this new political war is generally comforting for liberalism, but it requires a rethinking of this ideology, both politically and economically, "since this is the condition for restoring the legitimacy of democracy, which is no longer evident today» (Duclos, 2018).

As we can see, for Duclos, the genetic connection between liberalism and democracy is beyond doubt. I. Wallerstein, the creator of the world-system theory, approached this connection from a very different standpoint. For him, the collapse of the USSR «to an even greater extent testified to the collapse of liberalism and the decisive entry of the world into an era "after liberalism» (Wallerstein, 2003: 4), when the world will face systemic disorder and unprecedented political struggle within twenty-five to fifty years, causing a «strong sense of futility of political action of the 'traditional' type» (Wallerstein, 2003: 7-8). According to Wallerstein's predictions, the world was in for a decline of states and processes of disintegration of civil society as other types of consolidation emerged in society. «We are living in an era of «groupism» - the formation of groups with a protective character, of them striving to achieve self-consciousness, on the basis of which solidarity and the struggle for survival is consolidated simultaneously with the struggle against other similar groups» (Wallerstein, 2003: 10). That is why, according to Wallerstein, the world of 1990 $2025 / 2050$ will be characterized by a deficit of peaceful coexistence, stability and legitimacy. During this period, the sociologist and philosopher of politics predicted, the U.S. will roll back from its position as the dominant world power, which in turn will mean the decline of the existing worldsystems (Wallerstein, 2003: 29). One can only admire the accuracy of such a prediction, the incomplete part of which is also likely to come true.

In the course of his reflections, Wallerstein accurately highlighted the fundamental difference between liberalism and democracy: «Democracy and liberalism are not twin concepts, rather they oppose each other. Liberalism emerged as a means to counter democracy. It owed its emergence to the desire to curb dangerous classes, first in the leading countries and then in the world-systems as a whole. The liberal solution was to give them limited access to political power and a limited share of economic surplus value within limits that would not threaten the constant accumulation of capital or the state system on which it rested» (Wallerstein, 2003: 42).

So what awaits the world after the end of the systemic disorder, the period of bifurcation (around 2050 or 2075)? The answer is curious because it touches on the fundamental principles of the modern world order: "We will no longer live in a capitalist world economy. Instead, we will develop within a new order or orders, some new historical system or systems. And so, perhaps, relative peace, stability and lawfulness will reign again. But will this peace, stability and legality be 
better than the ones we knew before, or will they be worse? We do not know, but it depends on us» (Wallerstein, 2003: 49).

This prophecy proceeds from the understanding that liberalism is, in fact, totally contradictory, since its recognition of universal equality of rights is in practice rejected by the capitalist system. "But if this is openly acknowledged, the capitalist world economy will lose legitimacy in the eyes of the dangerous (i.e., disadvantaged) classes. And if the system lacks legitimacy, it will not survive» (Wallerstein, 2001: 143).

Let us now try to figure out which prediction of the future is most accurately realized today in the context of the politics of pandemic. Pandemic clarification is absolutely necessary because it is among the systemic phenomena radically changing the world, as reflected in many studies by scientists and reports by international organizations.

Looking at the world today, it is clear that liberalism has not only failed to enchant the world, but has transformed itself into forms that are clearly at odds with its fundamentals. Instead of marching peacefully across the planet, liberalism has undertaken (predominantly in Muslim countries) a series of aggressive actions to impose its principles by force, so one may wonder who was originally to blame for fulfilling Huntington's prediction of a clash of Western and Islamic civilizations! As a result, instead of the establishment of democracy in the East, the opposite process of the growth of the system of authoritarianism began, capturing today the Western countries as well. As Isabelle Lasser writes: «Since the early 2000s, democracies have been decaying from within, as well as sagging under attack from without. In a feral and post-historical world that serves as a refutation of Fukuyama, the American model began to wither. Authoritarian models have competed with it, trampling on certain freedoms and showing contempt for human rights, but sometimes with a more effective and direct form of government. Now the world tends to follow the Chinese model, which combines economic freedom with political control» (Lasser, 2019).

The coronavirus pandemic coincided with another downturn in the world economy, the timing of which cannot yet be predicted, was an extraordinary event that visibly showed that mankind is no good at predicting the future. Even without taking into account the likelihood of multiple waves of coronavirus, a sharp drop in the GDP of the European Union and the USA and a considerable increase in unemployment around the world are predicted (and are already happening). Accordingly, the double blow of pandemic and economic crisis strikes developing countries to an even greater extent.

Most of today's forecasts conclude with the disappointing conclusion that it may take years to overcome the social, medical and economic consequences of the current crisis. In these conditions another tendency emerges (after the tendency to reduce the gap between the prognosis and its approbation by the reality): a permanent lag in comprehending the crisis events and a lack of adequate and timely measures to overcome them.

Formulating preliminary conclusions, we note that the concept of F. Fukuyama as a whole has not proved its consistency, although representatives of neoliberalism are trying to identify ways out of this ideology from the theoretical and practical deadlock. As for S. Huntington's concept, it also showed its flaws. In today's political world, contradictions and clashes are growing not only between «alien» civilizations, but also between kindred civilizations, not to mention intracivilization contradictions, which have recently gripped the United States in particular, although they are sometimes preferred to be considered inter-racial clashes. 
We have to state that I. Wallerstein's concept was the most prescient prognosis. In this regard, we note that its main elements are of a post-non-classical nature, while the ideas of $\mathrm{S}$. Huntington and F. Fukuyama generally fit into the classical political analysis based on cause-effect relations. I. Wallerstein, widely involving synergetic ideas, builds prognostication as a system of political processes of emergence of order from chaos with the subsequent collapse of the established order, forming the conditions for the formation of the next chaos, covering the space of politics. It is interesting to note that I. Wallerstein quite deliberately includes in the political analysis the state of bifurcation, thus emphasizing the non-linear nature of political processes. And this makes it possible to identify in these processes the presence of discontinuities, pullbacks, branches of collateral growth, etc. Overall, for the American sociologist, the future is a bundle of (often contradictory) scenarios of varying degrees of probability, some of which may take place, while leaving room for less probable processes. The presence of bifurcation points indicates that in the political process, as in other synergetic processes, there are zones (points) of uncertainty, not allowing to base solely on the causal mechanism of forecasting. We emphasize again that since Wallerstein's forecasting turns into the formation of a number of possible scenarios unfolding in the form of non-linear processes with the presence of breakpoints and bifurcations, it is obvious that the concept of this scientist is fundamentally post-non-classical in nature.

Although, like any other, I. Wallerstein's concept in the future will be supplemented and refuted in some ways, there is no doubt that today this paradigm should become the methodological basis for predicting the political future of our world, to become a method of futurology research.

Consequently, it should take its rightful place in the system of education as a striking example of post-non-classical knowledge.

\section{New Ideas of the Philosophy of Future}

Let us assess the future of the twenty-first century, which began to take shape right before our eyes. How did previous events determine this future? What can be distinguished as mainstream and peripheral events that laid the groundwork for the future? Were these processes linear, or, on the contrary, non-linear with breakpoints and bifurcations?

Mohammad-Mahmoud Ould Mohamedou (deputy director and scientific head of the Geneva Center for Security Policy, professor at the Geneva Institute of International and Development Affairs) specifically identifies an era of two decades after the events of 11.10.2001, marked by the growth of neoliberal aggressiveness and expansionism (the interventionist era of the 1990s), which ends and transitions into a "post-coronavirus era» (Mohamedou, 2020).

In this interval, the author identifies four main phenomena that characterize the changing political world: the strengthening of etatism with increasing authoritarian tendencies, the expansion and deepening of the militarization of the world, the forced resignation of society to the practice of state surveillance of citizens and the beginning of the process of counter-globalization.

Stunned by crises and pandemics, people prefer to trade their rights for the protection of the state, allowing the latter to strengthen itself considerably and to resort, through information technology, to extreme measures to maintain security. Mohamedou predicts: "Surveillance, established as an increasingly less questionable global standard, will add the parameter of necessity to the widespread argument of utility. It is increasingly difficult to trace and monitor those practices that have been introduced in an emergency and without parliamentary consultation - China, Israel, 
Russia, and South Korea have already done so, introducing citizen tracking, digital monitoring of travel restrictions, requiring facial recognition, all again and always in the name of sacred security» (Mohamedou, 2020). Recall the hysterical «pro» and "contra» campaign at the beginning of the pandemic for the possible «chipping» of the world's population to overcome the coronavirus. This campaign was a test of humanity's willingness to sacrifice its rights and freedoms in the face of real and imagined risks and threats.

New limits to the interconnectedness of the world (multiplied by the pandemic), leading to increasing deglobalization, create not only economic but also existential vulnerabilities in societies, leading to increasing international disunity and national protectionism. Obviously, the picture presented demonstrates the world's retreat from the progressive development of globalization, a break between the past and the present, which carries with it a completely unpredictable impact on the future. This is in line with the author's suggestion that «perhaps the universal crisis that has occurred «will teach us to better understand both the world in which we live and our consumerist attitude toward it, which leads to the "orwellization of geopolitics» (Mohamedou, 2020). Such is the world of geopolitics since the beginning of the Coronavirus era, and its perception, as Wallerstein noted, hardly fits into the traditional understanding of political realities. Therefore, it should be recognized that the philosophy of the future is on the threshold of forming new ideas and concepts in its research.

In parallel, there is a growing number of studies which argue that, even before the pandemic, the imperfections of democracy and its rollback in a number of states, the growth of anti-liberal and anti-globalist sentiments, which led to national insularity, the strengthening of xenophobia, contributing to the strengthening of authoritarian regimes and their image, even if in a populist manner, became noticeable in the world. Explicit populism, we note, does not hinder, but rather contributes to the capture of Western countries by these sentiments in the context of the incessant influx of migrants into Europe.

It is no coincidence that «the pandemic has contributed to the polarization of the political world, a clash of ideologies that can no longer coexist peacefully. The most radical observers hold an alternative: either authoritarian regimes will fall as a result of fighting the pandemic, or democracies will begin a gradual departure from neoliberal ideology, which will undermine the foundations of the capitalist system» (Abasov, 2020).

The emergence of more balanced predictions in a pandemic crisis era is not yet evident, but that does not mean that they will not appear soon.

But how to live now, when the future has become most impenetrable? The answers are naturally varied, simultaneously embracing the practice of everyday life and the ethics of eternity. And the tone here is often set by philosophers. One of them, Marianne Durano of France, highlights scenarios of possible end-of-the-world living due to the prospect of ecological collapse (into which the outbreak of the pandemic fits perfectly). There are three lifestyles: optimistic, realistic, radical. The first of these assumes not so much the end of the world as the end of our consumerist, globalized world, the realization of which the philosopher, observing the modern development, doubts. The second - proceeds from the globality and irreversibility of threats to the entire planet, which could lead to the real end of the world in the struggle for dwindling resources, which could end in a nuclear war or critical climate disruption. The third attempts to turn the inhabitant of Earth into a philosopher "temperate and cheerful, preferring to change his desires rather than the order of the world, not to accumulate objects of his lust but to enjoy life, knowing that he is mortal" 
(Durano, 2019). But this requires abandoning the idea of «infinite economic growth», which makes the human world «indeterminate, that is, limitless and meaningless». "By destroying the idea of 'space' - a finite, limited, organized world - and replacing it with the idea of 'the universe' - an infinite and chaotic space - our modernity has created the conditions for an unprecedented ecological crisis. We are painfully discovering that there is no neutral space in our world, suggesting infinite expansion, and that it is above all a fragile ecosystem: the cosmos. The infinite world, theorized by modern philosophy, has long been considered immortal, but in reality it is aimless and risks causing our end» (Durano, 2019).

The coming form of human existence, if it takes place, must not only restore to humans the meaning lost in the days of industrial civilization, but also avoid the costs of the dangerous alliance between information technology and biotechnology, as Yuval Noah Harari, one of the foremost thinkers of our time, writes. The Israeli scholar believes that the threat lies in the fact that information technology is gradually beginning to access the human brain, learning the procedure of reading people's thoughts and understanding feelings, knowing their aspirations and needs more clearly than they do (Ram, 2019), which creates conditions for the revival of authoritarianism based on total population control.

"There are glaring inequalities between and within societies. Much of the information that is now the most expensive commodity is in the hands of a few states and companies, and mostly concentrated in the United States and China. The benefits of the technological revolution have accrued to only a few. If this phenomenon is accelerated, we will have the most unequal society in history. The elites will become superhuman, while most people will survive without any perspective and will lose all meaning. In the twentieth century, inequality meant exploitation, and the elite exploited the masses. Today, many people are no longer exploited and, as a consequence, they are good for nothing. To be worthless and uninterested is more dangerous than to be used» (Ram, 2019).

The greatest threat of modern technology, in Harari's assessment, lies in its promising ability to «create new beings with altered physical and mental abilities».

It is obvious that the majority of contemporary forecasts are alarmist in nature, they are value-colored with deep pessimism and apocalyptic sentiments. The natural question is: do these forecasts reflect the real state of affairs, or are they connected entirely with the sociocultural determinant of the authors of these forecasts? If we consider that the long-standing global economic crisis has revived class and racial clashes, long forgotten in Europe and America, against a backdrop of rising protest sentiments caused by the mass migration of refugees from Africa and Asia to Europe, if we add to this the growing strength of the second Cold War, the rise of populism and nationalist sentiment, it becomes clear that the predictions reflect the current reality. Paradoxically, it turns out that the existing world system of neoliberalism is ready to destroy its own child, globalization. And the first bell here is the disintegration processes in the EU, the central event of which was «Brexit», the social protests all over the world, the growing popularity of rightwing and nationalist parties all over Europe and especially in France, Germany, Austria and Italy, provoked by the chaos in the economy.

"The Western liberal business model is no longer considered an example to which the rest of us look up to. There are "counter-projects» in abundance, from China's digital totalitarianism and modern despotism, such as in Russia, to traditional absolutism in the Gulf countries. The openly demonstrated nationalism of actors such as Donald Trump also calls the liberal model into question. 
Societies are breaking up before our eyes into groups, each shouting for their own identity» (Mueller, 2019). Yet Wallerstein predicted the collapse of the economy of liberalism and the disintegration of society into groups of different identities at the end of the twentieth century!

Trade wars and sanctions policies have become alarming world events, engulfing not only opponents but also allies of the modern political and economic space. The intrinsic motivation of the social protest that is gaining momentum everywhere, in which the middle class is gradually being drawn in, is the struggle against neoliberalism and its main agents in the world. And if we remember what ideas neoliberalism promotes, it becomes clear that the growing struggle is against capitalism, which seems to have reached its natural limits of expansion in the process of globalization. That modern capitalism has long worked to the advantage of a limited, minuscule group of individuals is well illustrated by unbiased statistics:

From an annual report by the nonprofit Oxfam: «The fortunes of billionaires grew by $\$ 900$ billion in 2018, while the total resources of the poor half of humanity declined by 11 percent; 26 billionaires now hold as much money as the 3.8 billion poor people on the planet. In 2017, there were 34; the number of billionaires has doubled since the 2008 financial crisis; billionaires hide $\$ 7.6$ trillion from tax authorities, while the poorest $10 \%$ pay more taxes in proportion to their income than the wealthiest» (Mueller, 2019).

Meanwhile, the world is on the cusp of a fourth industrial revolution, the so-called Industry 4.0 (Schwab, Davis, 2019), updating production with information-networked, cybernetic systems, entailing enormous changes in the labor market, ecology, political systems, and even human identity, as they powerfully infiltrate the natural psychophysical organization of people. Increasingly evident are the impending risks and increasing general instability that could bring the world into a state of collapse. A new Cold War has already begun, having moved into the relationship between the U.S. and China.

It turns out that the world is waiting for deglobalization and fragmentation of the single economic space, which will bury the integration successes achieved, strengthening trade barriers and increasing the risk of another recession. This global slowdown in economic development involves the U.S., EU countries, China and Japan, in short, the states that have been the main actors in promoting the world of globalization. The alarming parallels with the times of communism and fascism sound alarming - the situation and state of mind of those times and those of today are very similar. Each country will have to cope with the growing threats and risks on its own, since the world is on the threshold of destructive processes of deglobalization, provoking isolationism as a global practice. This was graphically demonstrated by the results of the $50^{\text {th }}$ World Economic Forum in Davos (2020).

In 2020, it was no longer the meeting that the famous American journalist Anand Giridharadas described a year ago as «a family meeting of the people who destroyed the modern world». This time, the "family» gathered to discuss the sad result of what had happened: the climate crisis. Behind the plainly simplistic title of the Davos meeting were the accumulated problems of humanity: the contradictory results of globalization, the unmanageable economic crisis, the critical state of the environment, the deadlock of capitalism, represented by neoliberalism, which has revived a wave of social protest almost all over the world. This protest has become so aggressive that the captains of industry and finance have begun to think of ways to overcome the critical situation. Among them, the idea of phasing out the financing of fossil fuel extraction, now called the fuel of the 20th century, whose days are numbered. But the global risks 
are not limited to these. The cumulative risks of stagnation in the global economy, a fragmented cyberspace that threatens the potential of next-generation technologies, and civil society protests against political and economic conditions that exacerbate inequalities.

"High inequality, the rapid spread of technology, high risks and earnings in financial markets. This trend is similar to the situation of the 1920s, which ended with the collapse of markets in 1929». (Mueller, 2019) - noted IMF head Kristalina Georgieva in her speech in Davos.

The problem, meanwhile, is that the old tried-and-true methods no longer work, and this raises more fundamental dilemmas. One of them is whether capitalism is alive or dead? Paradoxically, some of the "captains» state bluntly: "Capitalism as we knew it is dead», because profit maximization permanently worsens already high levels of inequality on a planetary scale. Isn't that why, in many recent polls in Western countries, the number of respondents claiming that they would not want to live under capitalism is growing?!

Opponents of this view believe there is an alternative: digital technology, open borders, and multiculturalism can improve inequality. Regarding open borders and multiculturalism, the failed experience of Western countries and the entire United States in this area has shown that these «technologies» are prescribed exclusively for underdeveloped and developing nations. And in the case of digital technology (and the economy as a whole), the paradox is that it aims to destroy the systemic principle of capitalism - profit.

So can the proposed technologies save capitalism at a time when the world economy and its growth forecast are more dependent than ever on social and political processes that demonstrate the escalating tensions of the era of initial capital accumulation? And then there is the rise of rightwing and left-wing populist movements pursuing isolationist and extremist policies.

This is why cautious economists, putting aside their theoretical calculations, believe that the world is approaching a new crisis, pedaled by increasing turmoil, revolutions, and wars. They note that hot spots on the map often coincide with the locations of major oil reserves.

So, the organizers of Davos and representatives of big business are well aware of the critical problems that have arisen, but they are unanimously trying to prove that capitalism can still be saved from «death. All that is needed is firmness and the reforms necessary for the "patient» to recover. Thus, the founder of the Davos Forum, Klaus Schwab, revisits his old idea of «stakeholder capitalism» or «stakeholder capitalism», which has been widespread since the mid-1980s.

An enterprise (and its varieties) can no longer be viewed as a closed system, but must present itself in the context of its external and internal environment, its stakeholders. Transformed capitalism, having overcome its egoism, must take into account the interests and demands of these parties, combining profitability and profit with social responsibility and environmental protection.

Wonderful, but is this possible in practice? Let us not rush to an answer, even though these ideas are coming to life under the frenetic pressure of the street. Thus, business structures and civil society activists have entered the debate about the future of capitalism, with the latter increasingly winning the battle. But so far, the main role is played by the state, which acts as an arbitrator in debates that are no longer peaceful. And while in the past the state deemed it necessary to contain the excessive enthusiasm of the protesters, lately it has preferred to take a more neutral stance, albeit for populist purposes. Given this course of events, it is likely that in the near future the state will begin to force business to quickly address social and environmental responsibility issues.

For now, businesses prefer to concede only to the limits beyond which their true interests lie. How long will this stubbornness continue? Given the rapid development of the "network" 
protest, it seems that resistance will be overcome in the shortest possible time. And this is further evidence that the information revolution is not the panacea of capitalism, but its gravedigger.

But the problem is, as we have already noted, that the state itself, as an institution, is in deep crisis. First of all, it can be felt in the stagnant development of international organizations. The state, which is based on the political will of parties with narrow self-interest, is itself facing the problem of reform, as the opposing force - civil society - is gaining strength, capable not only of voicing its own interests, but also of defending them with the power of cohesion multiplied by the incredible possibilities of the virtual world.

No matter how the ideas of the future develop, it is clear that most of them are aimed against the principles of economic development of oil-producing countries, in particular post-Soviet countries, which include Azerbaijan.

\section{Conclusion}

To summarize, it can be noted that philosophy of the future, along with all the humanities and social sciences, is experiencing an era of change in the methodological apparatus, which should affect the quality of education, the change in methodological principles, and the worldview aspects of teaching. In this context, the best example is the concept of the future outlined at the end of the last century by the American sociologist I. Wallerstein. According to this concept, the crisis of liberalism began immediately after the collapse of the bipolar world, and the future politics within 25-50 years will be characterized by populism, authoritarianism, a decline in the value of democracy and liberalism. The very systemic disorder and chaos of this period will show the uselessness of the traditional type of political action. The forecast that the crisis period will be accompanied by a deficit of peaceful coexistence, stability and rule of law, the U.S. will roll back from the position of the dominant world power and the decline of the existing world system. Against this background, the concept of S. Huntington and, especially, F. Fukuyama revealed less prognostic accuracy.

Today the world is developing under the conditions of the unfolding of the processes of economic crisis and pandemic coronavirus, leading it to disintegration, deglobalization, growth of national narrow-mindedness and xenophobia. Under these conditions, it is not a «clash of civilizations» but a «war of all against all.

The choice of I. Wallerstein's concept to describe the modern political world and forecast its future development is explained by a number of its pragmatic factors: its post-non-classical nature, attraction of synergetic principles, such as bifurcation, interdependence and inter-transitions of order and chaos, non-linear nature of political processes, presence of uncertainty zones, gaps, reversals, branches of side growth, idea of future as a number of scenarios of different probability, consisting of them leaving space for a number of scenarios. I. Wallerstein's supplemented concept can become a methodological basis for predicting the political future of our world, to become a method of futurology research.

Practice confirms the theoretical forecasts of the American sociologist. Four phenomena emerge in the contemporary political world: the strengthening of etatism with an authoritarian tendency, the deepening militarization of the world, society's coming to terms with the practice of citizen oversight, and the beginning of the process of counter-globalization.

A growing number of sociological studies assert the conclusion that, even before the pandemic, the flaws of democracy and its rollback in a number of states, the growth of anti-liberal and anti-globalization sentiments have become visible in the world, leading to national insularity, 
the strengthening of xenophobia, contributing to the growth of authoritarian regimes and their image, even if in populist terms. In turn, populism contributes to the capture of Western countries by these sentiments in the context of the incessant influx of migrants into Europe.

Under these conditions, the alternative future lies in the question: Will authoritarian regimes fall, or will democracies begin a gradual departure from neoliberal ideology, culminating in the collapse of the capitalist system?

The coming form of human existence must not only restore to humans the meaning lost in the days of industrial civilization, but also avoid the costs of the dangerous alliance between information technology and biotechnology.

Most of today's prognoses are alarmist; they are value-colored with deep pessimism and apocalyptic sentiments. The natural question is: do these forecasts reflect the real state of affairs, or are they related entirely to the socio-cultural determinant of the authors of these forecasts?

Whatever the case may be, each country will have to cope with the permanent threats on its own, since the world is on the threshold of destructive processes of deglobalization, growth of isolationism, nationalism and ultra-right-wing ideology.

Under these conditions, the state itself as an institution is in deep crisis. This means that new centers of control over local, regional and global processes must emerge.

\section{References:}

Abasov, A. (2020). Pandemic of the world of globalization. https://www.astna.biz/ext/news/2020/6/subsc/pol-security/ru/1536.htm 2020 June 30.

Duclos, M. (08.11.2019). Liberal democracy no longer seems to be a compulsory example to follow Le Monde. InoPressa. https://www.inopressa.ru/article/08Nov2019/lemonde/michel.html/.

Durano, M. (24.07.2019). We are not the cause of the end of the world, but the end of the world gives us a reason: to live as well as possible. InoPressa. https://www.inopressa.ru/article/24Jul2019/lemonde/endoftime.html.

Fukuyama, F. (2015). The end of history and the last man. M., Publishing house: AST.

Huntington, S. (2003). The Third Wave. Democratization at the End of the Twentieth Century. Moscow: ROSSPAN.

Huntington, S. (2015). The clash of civilizations. M., Publishing house: AST.

Lasserre, I. (06.11.19). Fukuyama's restful world erased by Huntington's clash of civilizations. InoPressa. https://www.inopressa.ru/article/26 Nov2019/lefigaro lemonde/endoftime.html.

Mohamedou, M-M. (04.05.20). Y. Geopolitics after the coronavirus. Le Temps. InoPressa. https://www.inopressa.ru/article/04May2020/letemps/geopolitik.html.

Mueller, H. (21.01.19). Zombies in the Snow. Der Spiegel. InoPressa. https://www.inopressa.ru/article/21Jan2019/derspiegal/endoftime.html/.

Ram, E. (12.07.19). Yuval Noah Harari: Technology threatens liberal democracy. Le Temps. InoPressa. https://www.inopressa.ru/article/12Jul2019/letemps/technology.html.

Schwab, K., \& Davis, N. (2019). Technologies of the Fourth Industrial Revolution. M.: Exmo, 2019.

Wallerstein, I. (2001). Analysis of World Systems and the Situation in the Modern World. SPb: Universitetskaya kniga Publisher.

Wallerstein, I. (2003). After Liberalism. M: Unitorial URSS. 


\section{Перспективи майбутнього та глобальне лідерство: ідеї та концепції}

Ali Abasov, Doctor of Science in Philosophy, Professor, Head of Department of Modern Problems of Philosophy, Institute of Philosophy, National Academy of Sciences of Azerbaijan

У статті проведено порівняльний аналіз концепцій С. Хантінгтона, Ф. Фукуями та I. Валлерстайна з метою окреслити теоретико-методологічні засади майбутнього. Постнекласичні ідеї І. Валлерстайна, що передвіщають кризу лібералізму та необхідність трансорормації основ західної демократії, крах парадигм розвитку капіталізму, зростання взаємозв'язку популізму та авторитаризму, формування нового перехідного періоду, що характеризується системним безладдям (хаосом), гостра політична боротьба за принципом "всі проти всіх», відсутність мирного співіснування, стабільності та законності найбільш адекватно відображені в сучасному політичному процесі. загалом, майбутнє постає як зв'язок сценаріїв різного ступеня ймовірності, лише деякі з яких, минаючи зони невизначеності, можуть мати місце. Такий підхід сутmєво змінює підхід до вищої освіти та викладання гуманітарних та соціальних наук.

у другій частині статті розглядаються питання визначення майбутнього за попередніми подіями, виокремлюються основні та периферійні події, які закладають основу майбутнього. Зазначається, що ще до пандемії стали помітними вади демократії та зростання антиліберальних та антиглобалістських настроїв у світі, що призводило до національного ізолячіонізму, посилення ксенофобії, сприяючи зростанню авторитарних режимів та їх іміджу в світі, популізму. Наголошується, що більшість сучасних прогнозів носять алармістський характер, вони ціннісно забарвлені глибоким песимізмом та апокаліптичними настроями.

Кожній країні доведеться впоратися із загрозами самостійно, адже світ має пройти через деструктивні процеси, щоб встановити новий порядок, що підтверджує прогнози Валлерстайна.

Як бачимо, мова йде про серйозну редукцію фрілософії освіти та ії системних парадигм.

Ключові слова: майбутнє, фрілософрія часу, вища освіта, постнекласичне пізнання, прогнозування, глобальне лідерство, політичний аналіз. 